\title{
ONLINE DIGITAL PLATFORMS DURING COVID-19 IN EFL CLASSES: VISUAL IMPAIRMENT STUDENT' PERCEPTION
}

\author{
Sitti Maryam Hamid \\ Universitas Negeri Surabaya, Indonesia \\ sitti.19007@mhs.unesa.ac.id
}

\begin{abstract}
Due to the COVID-19 Pandemic, the government decided to implement work and learn from home. Teachers are expected to teach online. It also applied to teaching and learning English. Thus, Google Classroom, WhatsApp, and Zoom are commonly used as online learning platforms by EFL teachers and students during the pandemic. The online digital platforms are also used as the main tool to provide teaching materials for the sighted student for Visual Impairment student (VIs). The present study investigates how visual Impairment students (VIs) perceive utilizing Digital Platforms in online learning, the barriers VIs faced in using Digital Platforms, and the kinds of Digital Platforms that appropriate for Visual Impairment student (VIs). The study involved one Visual Impairment student (low vision) in one of the private universities of Makassar, South Sulawesi. Questionnaires and interviews were used to collect data. It applied descriptive qualitative research using the survey method. The results of the study showed that Visual impairment has a positive response towards Google Classroom, WhatsApp, and Zoom in understanding the content, improving the ability to use various digital platforms in learning, presenting more interesting teaching materials, selecting of Digital Platforms by English Language skill, and hindering of utilizing Digital Platform. Even though slow-speed internet connectivity, takes longer, and vague learning instruction was considered barriers in using Digital Platforms. Besides, Zoom is a digital platform that appropriates for VIs; Zoom is a video conferencing learning platform that offers VIs an opportunity to respond in real-time and there is a recording system that records the learning process from start to finish.
\end{abstract}

Keywords: COVID- 19; Google Classroom; WhatsApp; Zoom; Visual Impairment student (VIs); Perception

\section{A. INTRODUCTION}

oronavirus disease 2019 (COVID-19) become a global pandemic, was first discovered in Wuhan China in December 2019 and first entered and spread in Indonesia in March 2020, so that the government officially issued Government Regulation No 21/2020, which regulates large-scale social affairs as the responsibility of COVID-19, to anticipate the widespread of this virus. The Minister of Education and Culture of the Republic of Indonesia has been advising online learning in areas affected by COVID-19 since 16 March 2020 (Mendikbud, 2020b). Shortly thereafter the Minister of Education and Culture of Indonesia ordered all education units to execute online learning on 24 March 2020, with the increase in COVID-19 and the protection of students, teachers, and all educational staff (Mendikbud, 2020a). Moreover, the Republic of Indonesia National Disaster Management Authority has decided to extend the emergency period for the COVID-19 pandemic to 29 May 2020 (BNPB, 2020). This policy demands that students and teachers study from home. During 
the COVID-19 pandemic, it replaced face-to-face learning with online learning. For both students and teachers, this is a new challenge for online learning.

Responding to the Government Regulation, the Minister of Education and Culture (Mendikbud) issued Circular No. 4 of 2020, one of the contents of the Circular Letter is related to learning from home, the use of online learning during a pandemic. The COVID-19 pandemic causes class suspensions, resulting in online learning (Moorhouse, 2020). Online learning analysis is usually a study of independent online learning resources, methodologies, and unique environments in a mixed study program. Moreover, online learning is a set of learning activities in a subject delivered through a network providing access and exchange of knowledge (Atmojo \& Nugroho, 2020). Students' attitudes, interpretation, evaluation, assessment, happiness, and success are commonly emphasized (Sun, 2014). This is in line with Sujarwo, et.al., 2019), who think that learning can be done easily by the student in all areas since space and time are not restricted. Online learning is education that takes place over the net. It's usually said as "elearning" among different terms. However, on-line learning is simply one form of distance learning.

Online learning is carried out using Jitsi Meet, Google Meet, Google Classroom, Whatsapp, Zoom, etc. However, the most frequently used digital platforms in this study are Google Classroom, Whatsapp, Zoom. Those platforms are most frequently used in teaching and learning during the COVID-19 pandemic. The use of the digital platform also varies. In general, the teacher will adjust to the subject taught. And the condition of the students that he/she teaches.

Furthermore, online learning is also applied equally to the elementary to higher education. The same applies to students who learn online, normal students even students with special needs. This study was restricted to visual impairment students. Visual impairment is the functional restriction of the eye or eyes or the vision system (WHO, 2003). The visual impairment student has decreased / weak visual acuity and abnormalities in the area of view or the visual system. While this condition has been supported by a certain instrument (corrected), it still harms the educational process and the person's outcome. According to the Education Improvement Act of Persons with Disabilities (IDEIA, 2004), visual impairment is defined as a visual impairment that affects the educational performance of a child even if corrected. In this case, the student under investigation is low vision. Children with low vision use vision as the main means of learning but information visual with tactile and auditory input (Heward, 2017). 
Therefore, this study focused on Visual Impairment student (VIs) perceive of utilizing Digital Platform on COVID-19 in online teaching and learning English, the barriers faced by Visual Impairment student (VIs) in utilizing Digital Platform, and kinds of Digital Platforms that appropriate for Visual Impairment student (VIs) especially, in learning English.

\section{B. REVIEW OF LITERATURE}

During COVID-19, online learning has changed the way is taught and learned. It from face-to-face in the classroom became a virtual meeting by using digital platforms. The use of digital platforms contributes significantly to education, including achieving online learning goals. Various digital platforms can also support online learning implementation. For example, virtual classes using services like Google Classroom, Edmodo, Zoom, etc (Iftakhar, 2016; Sciences, 2020) and instant messaging applications like WhatsApp (So, 2016). According to Raad (2020), online learning has helped our students learn in homes during the COVID-19 crisis and using applications such as Zoom, Teams, Veev, Google Classroom, and many others. In this study, the researcher focused on utilizing Google Classroom, WhatApp, and Zoom in teaching and learning.

First, Google Classroom is an application that is so simple to use it doesn't take too many spaces on the memory of your smartphone, and it helps your teacher and student keep track of the lessons. Users can create a virtual class where they can function as in a conventional class, but save more time, money, and space. Google Classroom is a learning platform that can be dedicated to any educational field that is designed to help find a way out of the difficulties experienced in making paperless assignments. Iftakhar (2016) says that Google classroom enables professors to spend more time and less time on paperwork. There are several previous research related to utilizing Google Classroom. According to Tinungki \& Nurwahyu (2020), the Google Classrooms implementation as an e-learning platform is categorized as good by learning outcomes and student responses. Besides, Okmawati (2020) found that the use of this platform is effective. It is one way that schools and teachers can offer students e-learning which is attractive to students, while teacher learning is a process that is transformed into virtual classes. Sukmawati \& Nensia (2019) stated that this research helped students better understand using Google classroom by decision-makers of higher education organizations. It is assumed that helped to measure the student awareness of the technology mentioned previously.

Second, WhatsApp is a mobile messaging cross-platform application that sends messages via the internet (Speroff, 2016). This application offers useful features to support education and learning in English. WhatsApp then, Alshammari, et.al.,(2018) state, allows teachers to play a 
more facilitating role in their teaching. Teachers can facilitate their English teaching features. Some previous studies related to utilizing WhatsApp. Susilawati \& Supriyatno (2020) revealed that analytical and discussion results could be concluded by using WhatsApp to increase learning motivation in the era and post-pandemic Covid-19. Sujarwo, et.al (2020) found that WhatsApp is the most suitable application used by lecturers and students. It can be seen that students' views on online learning are positive in the context of the Covid-19 Pandemic. Asmara (2020) said that WhatsApp is a platform that fits the student's and lecturer's needs in virtual classroom learning during the COVID-19 pandemic.

Third, Zoom is a cloud-based service offering meetings and webinars and the ability to share content and video conferencing. For example, it helps English teachers in frictionless environments to bring their students together to do more. Zoom is the leader in modern business video communication with a reliable, user-friendly cloud platform for video and audio conferencing, working together, chatting, and webinars across mobile devices, desktops, telephones, and room systems. There are some previous studies related to utilizing Zoom. Lowenthal, et.al (2020) stated that many faculties, including teacher educators, have chosen to convert their courses to live synchronous web meetings using web conferencing tools such as Zoom. (Destianingsih \& Satria, 2020) stated that the effective tool that can be utilized in explaining the subject and as the virtual tool to replace face to face meeting is the Zoom application.

Moreover, perception is how the information from the outside environment is selected, received, organized, and interpreted to make it meaningful to people. Following it, Michotte (2017) develops perception as a phase of the total process of action which allowing us to adjust our activities to the world, we live in. Here, the students' perception can be described as the developed opinion after a certain experience needs adjustment. There are some previous studies related to students' perception utilizing online learning during COVID-19. According to Agung et al., (2020) indicate that accessibility is still a major factor in the success of online learning. Online learning for STKIP Pamane Talino's English Language Study Program requires more friendly platforms to increase student participation. Then, Nugroho, et al., (2020) showed that students' positive perception of the use of Omega $\mathrm{T}$ and Google classroom in Dian Nuswantoro University S1 English Study Program is a translation course during COVID-19.

Therefore, similarities and differences between the previous studies in this study. Similarities with this research: almost all of these studies examine online learning using various digital platforms, which are the impact of the COVID-19 pandemic. Research subjects are 
generally English students in higher education. Whereas the difference between previous research and this research focuses on visual impairment students.

\section{METHOD \\ Research Design}

This present study focused on Visual Impairment students (VIs) perceive utilizing Digital Platforms in online learning, the barriers VIs faced in using Digital Platforms, and the kinds of Digital Platforms that appropriate for Visual Impairment student (VIs) during COVID-19. Descriptive qualitative research is used in this study. Creswell (2014) notes that qualitative research begins with assumptions, general perspectives, theoretical frameworks, and challenges. Phenomena in individuals and groups can be solved by employing formulas. Using qualitative descriptive research, researchers can find the instrument to collect data more flexibly. A descriptive research framework has been chosen using a survey method to achieve the research objective and to provide the answer to the question. The main purpose of the surveys, as mentioned by Fraenkel and Wallen (2009), is to describe the characteristics of a population and how members spread across some variables.

\section{Data Collection}

The participant of this present study is one visual impairment student categorized as low vision. The participant originates from a private university in Makassar, South Sulawesi. This study gathered data using a questionnaire and an interview. To know visual impairment students' experiences were surveyed using an online questionnaire. Moreover, to find deeper answers from the visual impairment were also interviewed. The survey used the close-ended questionnaire, which was adapted from Cakrawati (2016). While open-ended questions were used in the interview, it helps to gather in-depth qualitative data. The questionnaire consists of 15 statements, 13 positive statements, and 2 negative statements that used the model Likertscale (Sugiyono,2017). It was carried out by Google Form. The close-ended questionnaire was conducted to identify low-vision students' perception of the effectiveness of using the Digital Platform on COVID-19 in online teaching and learning English, such as Zoom, Google Classroom, and WhatsApp. In the meantime, an interview consisting of questions about the barriers faced by Visual Impairment in utilizing Zoom, Google Classroom, and WhatsApp was conceived for a detailed explanation and description. The interview was also conducted to investigate kinds of digital platforms suitable for students of visual impairment (VIs). It was carried out by telephone.

\section{Data Analysis}


The data from low vision students in the questionnaires were classified in each statement and then interpreted as descriptive. The questionnaire data was used to define the VIs impairment responses of the application of the digital COVID-19 platform for online teaching and learning English by students as Zoom, Google Classroom, WhatsApp. All the data from the interview were transcribed and analyzed for repetition of the barriers to online English teaching through the digital COVID-19 platform and kinds of digital platforms suitable for students with visual impairment (VIs).

\section{FINDINGS AND DISCUSSION}

\section{Findings}

This section presents and discusses research findings relating to the perception of the student with visual impairments of the use of English as a Foreign language (EFL) online learning platforms. The discussion is shown by interpreting the results in the tables developed with the results of the interview. The results were obtained from one student with visual impairment (VI). Google Classroom, WhatsApp, and Zoom have been used in English during pandemics during at least one half-year by the visual impairment student. The findings from the student questionnaire are shown in Table 1.

Visual Impairment student (VIs) perceive utilizing Digital Platform on COVID-19 in online teaching and learning English

Table. 1 Students' Perception of utilizing Google Classroom, WhatsApp, and Zoom

\begin{tabular}{|c|c|c|c|c|c|}
\hline \multirow{2}{*}{\multicolumn{2}{|c|}{$\begin{array}{l}\text { No. Statement } \\
\text { Assisting VIs in Understanding the Content and Purposes }\end{array}$}} & \multicolumn{4}{|c|}{ Students' Responses } \\
\hline & & $\mathrm{D}$ & $\mathrm{N}$ & A & SA \\
\hline 1. & $\begin{array}{l}\text { The reference materials (videos, PowerPoint files, articles) } \\
\text { and assignments published by my teacher in Google } \\
\text { Classroom, WhatsApp, and Zoom help me improve my } \\
\text { learning and better understand the contents/ themes of the } \\
\text { lesson. }\end{array}$ & & & $\sqrt{ }$ & \\
\hline 2. & $\begin{array}{l}\text { It's convenient for Google Classroom, WhatsApp, and } \\
\text { Zoom to use especially when submitting assignments. }\end{array}$ & & & $\sqrt{ }$ & \\
\hline 3. & $\begin{array}{l}\text { Google Classroom, WhatsApp and Zoom online activities } \\
\text { and discussions can encourage me to learn more about the } \\
\text { lesson. }\end{array}$ & & & $\sqrt{ }$ & \\
\hline \multicolumn{2}{|c|}{$\begin{array}{l}\text { Improving the VIs' Ability to Use Various Digital Platforms in SD } \\
\text { Learning }\end{array}$} & $\mathrm{D}$ & $\mathrm{N}$ & $\mathrm{A}$ & SA \\
\hline 4. & $\begin{array}{l}\text { The use of Google Classroom, WhatsApp, and Zoom saves } \\
\text { effort and time }\end{array}$ & & & $\sqrt{ }$ & \\
\hline
\end{tabular}




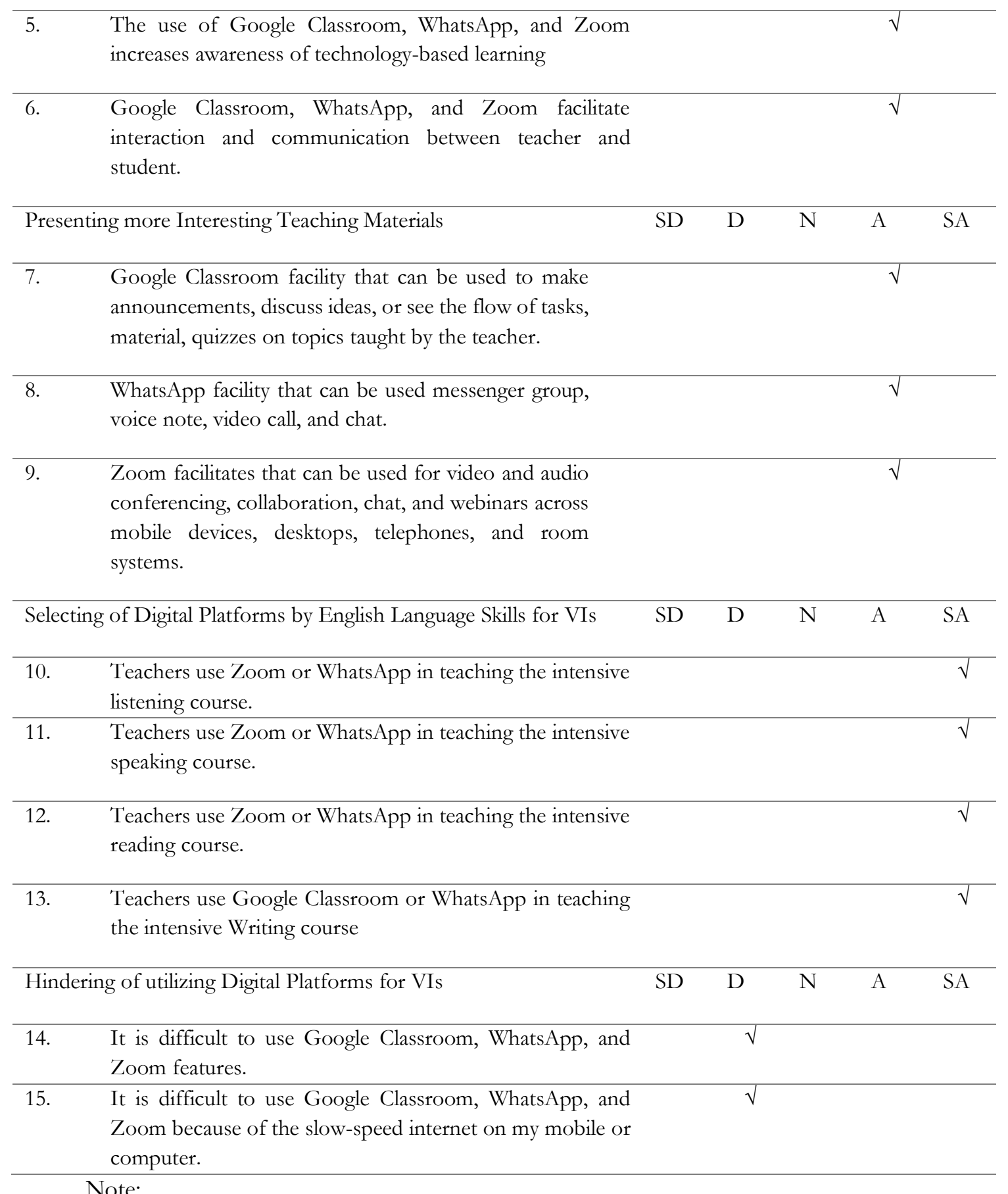
SD: Strongly Agree
D: Disagree
N: Neutral
A:Agree
SA: Strongly Agree

Based on the questionnaire data above, it appears that students with visual impairments are responding positively to learning English using digital platforms such as Google Classroom, WhatsApp, and Zoom. There are five key statements in the questionnaire data, 1-13 statements were positive statements while 14-15 were negative statements. First, assisting visual impairment students in understanding the content and purposes shows that VIs agrees that digital platforms increased the content understanding, easier in collecting assignment and online discussion. 
Second, improving the visual impairment students to use the various digital platform in learning shows that VIs agree with digital platforms that demonstrate the effectiveness of effort and time, awareness of the use technology in learning and facilitate interaction and communication. Third, presenting more interesting teaching material found that VIs agree with Google Classroom, WhatsApp, and Zoom with various features that make it more interesting to display teaching materials. Then, selecting digital platforms by English language skill shows that VIs strongly agree with the digital platforms that are adapted in teaching English skills. The last, hindering of utilizing digital platforms shows that VIs disagree with the difficulties in using digital platforms features and internet connectivity. Based on the findings, most of the statement visual impairment agreed on utilizing the digital platform in learning English.

\section{Barriers Visual Impairment student (VIs) faced in utilizing Digital Platform}

The researcher found the other data from the Visual Impairment students' interviews related to barriers that they faced. The researcher found the data about the impact of online learning as follow:

I believe that there are positive and negative impacts; the positive impact of online learning can be learned anywhere and reducing the risk of corona's virus transmission due to a lack of association. Whilst the negative impacts are the enthusiasm for learning, given that the atmosphere in learning differs greatly from the classroom situation, it's extremely ineffective, especially if we live in a remote environment that has failed to reach an adequate network, online learning does not take place regularly, for example, students always use the off mode on their videos.

The interview results indicate that online learning can be carried out everywhere. Online learning appears to be the best option for teaching and learning in a pandemic situation-19 especially true in social distancing situation; however, online learning has a negative impact. Due to adequate network, the student has difficulty accessing online learning and must constantly. The lack of activeness participates of the students in learning.

Furthermore, the researcher found the data about how to use digital platforms to learn about visual impairment and the barriers as follows:

I use this digital platform differently. If the lecturer uses Zoom, I set the schedule of meetings on my phone, then the link that has been shared will be clicked. If the lecturer uses WhatApp, I will enter the group of courses that the lecturer has taken. If the lecturer uses Google Classroom, I log in via an email account that I have created as a student to the course group that the lecturer has created. I use TalkBack on my handphone while I use Non-Visual Desktop Access on my laptop as a screen reader to apply digital platforms. 
Hamid, Online Digital Platforms...

The result of the above interview found that Visual Impairment student uses a screen reader tool so that Visual Impairment student can understand the instructions used on the platform more easily.

Moreover, the researcher found the data about the barriers of utilizing digital platforms as follows:

In using Google Classroom, I feel burdened by deadlines for assignments that are given if the time has elapsed, and then assignments cannot be entered again. Moreover, using the WhatsApp chat that is included in the group is always unnecessary and undirected so it takes time to check the chat that the lecturer gives. While in using the Zoom network stability is a hindrance and requires a large quota because I have to be 'ON' from the start until the lecture is over.

The result indicates that Visual Impairment students find it difficult to complete their assignments. Visual Impairment student is given limited time on the google classroom application. In the WhatsApp application, the overlapping chat, while the zoom is a large quota or a stable network.

Consequently, the barriers faced by Visual Impairment studens depend on what platform is used because it has limitations so that platforms that use Visual Impairment student time estimates will find it difficult to adjust. Also, unstable internet network connectivity is a barrier for him.

\section{Kinds of Digital Platforms that appropriate for Visual Impairment student (VIs)}

The researcher found the other data from the Visual Impairment students' interviews related to kinds of digital platforms that appropriate for Visual Impairment student as follow:

I'm more appropriate and like Zoom. Because learning through the Zoom media is clearer and more comprehensive. Video conference media conduct lecturers face-to-face. To record the learning process, see even if it is a vague presentation by a friend, and at the end of the lesson, hear the lecturers' comments and comments. By Zoom, the teaching material can be fully finished per meeting. Because, even though I am a visual impairment in the low vision category, if the font size is standard and the switching is not too rapid, I can see still a display of teaching materials or presentations shown on the share screen. Moreover, I use my hearing to complement the information I lack in view. As a student with special needs, the features of Zoom can satisfy my learning needs.

The result of the interview shows that Zoom is an application that integrates audio and video to suit the needs of the student with visual impairment who use audio to complement visual constraints. Therefore, Zoom is a digital platform that is appropriate for visual impairment students. It works with audio and video, making it easier for him to analyze the material. 


\section{Discussion}

The result of the students' in the term of perception, barriers, and appropriate digital platforms revealed that visual impairment student has positive responses. As a tool to share and submit the assignment, Google classroom could be used. While WhatsApp is used to give instructions or explanations about the subject to use a note or short video as tools and media for teachers. Zoom could be delivered and presented teaching material by video conference. It related to Amin \& Sundari, (2020) revealed that the video conferences used in Cisco WebEx Meetings, Google Classroom (Learning Management System), and Messenger (WhatsApp), have been shown to be highly positive in all criteria. In particular, authenticity and meaning were the most prominent aspects of the Cisco WebEx meeting. In the meantime, GC and WhatsApp reached the highest possible levels of criteria for language learning potential, focus, and authenticity. Moreover, the study by Wichadee (2013) found a similar result that using video and learning management technology was a new learning experience and encouraged them to take greater responsibility and to receive fast feedback online. Asmara (2020) also said that WhatsApp is a platform that recommends and fit the student's and lecturer's needs in virtual classroom learning during the COVID-19 pandemic.

In addition, the current findings on the survey using open-ended interviews show that the appropriate digital platform used for visual impairment during the online class was Zoom. It is supported by Sciences (2020) said that using Zoom increases medical students' positive outcomes in learning English while living in remote areas.

\section{E. CONCLUSION}

Based on the results of the study referred to above, despite the barriers Visual Impairment student face, it can be concluded that Visual Impairment student has a positive perspective on online learning during the COVID-19 pandemic. Visual Impairment student believes that online learning is very helpful in pandemics, albeit not completely efficient. The existence of several barriers to utilizing digital platforms on online learning is expected to be evaluated in the future in such a way that it is always ready to face such a situation. Based on the student's perspectives in this online learning research in the COVID-19 pandemic, the government, teachers, and schools should strive to adapt to the student situation, such as lack of financial support, access to the Internet, and specific policies for special need students. Furthermore, the study provides evidence that Zoom applications could be an effective and efficient learning platform for Visual Impairment student (low vision) with supporting features (recording, 
Hamid, Online Digital Platforms...

chatting, and video conference). Future researchers could explore this topic with more rigorous methods of data analysis, involve more subjects, and contrast more variables.

\section{REFERENCES}

Agung, A. S. N., \& Surtikanti, M. W. (2020). Students' Perception of Online Learning during COVID-19 Pandemic: A Case Study on the English Students of STKIP Pamane Talino. SOSHUM: Jurnal Sosial Dan Humaniora, 10(2), 225-235. https://doi.org/10.31940/soshum.v10i2.1316

Alshammari, R., Parkes, M., \& Adlington, R. (2018). Using WhatsApp in EFL Instruction with Saudi Arabian University Students. SSRN Electronic Journal, January. https://doi.org/10.2139/ssrn.3094526

Amin, F. M., \& Sundari, H. (2020). EFL Students' Preferences on Digital Platforms during Emergency Remote Teaching: Video Conference, LMS, or Messenger Application? Studies in English Language and Education, 7(2), 362-378. https://doi.org/10.24815/siele.v7i2.16929

Asmara, R. (2020). Teaching English in a Virtual Classroom Using Whatsapp During Covid-19 Pandemic. In Language and Education Journal (Vol. 5, Issue 1, pp. 16-27). http://ejournal.uniski.ac.id/index.php/LEJ/article/view/152

Atmojo, A. E. P., \& Nugroho, A. (2020). EFL Classes Must Go Online! Teaching Activities and Challenges during COVID-19 Pandemic in Indonesia. Register Journal, 13(1), 49-76. https://doi.org/10.18326/rgt.v13i1.49-76

Destianingsih, A., \& Satria, A. (2020). Investigating Students' Needs for Effective English Online Learning During Covid-19 for Polbeng Students. ELT-Lectura: Studies and Perspectives in English Language Teaching , 7( 2), 147-153

Iftakhar, S. (2016). Google Classroom: What Works and How? Journal of Education and Social Sciences, 3, 12-18.

Lowenthal, P., Borup, J., West, R., \& Archambault, L. (2020). Thinking Beyond Zoom: Using Asynchronous Video to Maintain Connection and Engagement during the COVID-19 Pandemic. Journal of Technology and Teacher Education, 28(2), 383-391.

Moorhouse, B. L. (2020). Adaptations to a Face-to-Face Initial Teacher Education Course 'Forced' Online due to the COVID-19 Pandemic. Journal of Education for Teaching, 00(00), 1-3. https://doi.org/10.1080/02607476.2020.1755205

Nugroho, R. A., Basari, A., Suryaningtyas, V. W., \& Cahyono, S. P. (2020). University students' Perception of Online Learning in Covid-19 Pandemic: A Case Study in a Translation Course. Proceedings - 2020 International Seminar on Application for Technology of Information and Communication: IT Challenges for Sustainability, Scalability, and Security in the Age of Digital Dismption, ISemantic 2020, 225-231. https://doi.org/10.1109/iSemantic50169.2020.9234251

Okmawati, M. (2020). The Use of Google Classroom during Pandemic. Journal of English Language Teaching, 9(2), 438. https://doi.org/10.24036/jelt.v9i2.109293

Raad, B. (2020). The Role of E-Learning in Covid-19. International Journal of Creative Research 
Thought, 8 (3) 3135-3138

Sciences, P. (2020). Zoom Technology as an Effective Tool for Distance Learning. Buletin of Science and Practice. 6(5), 457-460. https://doi.org/10.33619/2414-2948/54/61

So, S. (2016). Internet and Higher Education Mobile Instant Messaging Support for Teaching and Learning in Higher Education. The Internet and Higher Education, 31, 32-42. https://doi.org/10.1016/j.iheduc.2016.06.001

Sukmawati, S., \& Nensia, N. (2019). The Role of Google Classroom in ELT. International Journal for Educational and Vocational Studies, 1(2), 142-145. https://doi.org/10.29103/ijevs.v1i2.1526

Sun, S. Y. H. (2014). Learner Perspectives on Fully Online Language Learning. Distance Education, 35(1), 18-42. https://doi.org/10.1080/01587919.2014.891428

Susilawati, S., \& Supriyatno, T. (2020). Online Learning Through WhatsApp Group in Improving Learning Motivation in the Era and Post Pandemic COVID -19. Jurnal Pendidikan: Teori, Penelitian, dan Pengembangan , 5 (6) 852-859

Tinungki, G. M., \& Nurwahyu, B. (2020). The Implementation of Google Classroom as the ELearning Platform for Teaching Non-Parametric Statistics during COVID- 19 Pandemic in Indonesia. International Journal of Advanced Science and Technology 29(4), 5793-5803.

Wichadee, S. (2013). Facilitating students' learning with hybrid instruction: A comparison among four learning styles. Electronic Journal of Research in Educational Psychology, 11(1), 99116. https://doi.org/10.25115/ejrep.v11i29.1559 